Vol. 4, Issue.6, Nov-Dec 2021, page no. 40-62

To cite this article: Marsudi, H.R. Partino, Bambang Nugroho, D. S. Mabui, Roni Bawole, Syafrudin Raharjo, Anton Sineri, and Andoyo Supriyantono (2021). LAYOUT ANALYSIS OF GREEN CAMPUS IMPLEMENTATION IN THE DEVELOPMENT OF SPORTS FACILITIES AT THE UNIVERSITY OF PAPUA, MANOKWARI, International Journal of Education and Social Science Research (IJESSR) 4 (6): 40-62

\title{
LAYOUT ANALYSIS OF GREEN CAMPUS IMPLEMENTATION IN THE DEVELOPMENT OF SPORTS FACILITIES AT THE UNIVERSITY OF PAPUA, MANOKWARI
}

\author{
Marsudi $^{1}$, H.R. Partino ${ }^{2}$, Bambang Nugroho ${ }^{3}$, D. S. Mabui ${ }^{4}$, Roni Bawole ${ }^{3}$, Syafrudin Raharjo ${ }^{3}$, Anton Sineri ${ }^{3}$, \\ and Andoyo Supriyantono 5 \\ ${ }^{1} \mathrm{PhD}$ Student of Environmental Science, Universitas Papua, Manokwari, Indonesia \\ ${ }^{2}$ Department of Education, Universitas Cenderawsih, Jayapura, Indonesia \\ ${ }^{3}$ Postgraduate Program, Universitas Papua, Manokwari, Indonesia \\ ${ }^{4}$ Department of Civil Engineering, Universitas Yapis Papua, Jayapura, Indonesia \\ ${ }^{5}$ Department of Animal Husbandry, Universitas Papua, Manokwari, Indonesia
}

DOI: http://dx.doi.org/10.37500/IJESSR.2021.4605

\begin{abstract}
This research aims to uncover layout analysis of the implementation of green campuses in the development of sports infrastructure at the University of Papua, Manokwari. The assessment method employs a quantitative approach by scoring the results of questionnaire distribution. The implementation assessment of the green campus indicator for the sports center plan on the UNIPA campus is based on the results of the distributed questionnaire, which is determined by first determining the stakeholders involved in the activity, either directly or indirectly. The population is chosen based on the researcher's desire to conduct research. This study's sample included stakeholders involved in activities such as planning consultants, construction contractors, the government, lecturers, students, and members of the general public. There will be 120 samples distributed. Based on statistical calculations, it can be seen that the planned return rate of the questionnaire is 78 percent, and the research sample will be 51 (71 percent). It is because some respondents deemed the questionnaire inappropriate. After all, the data was not filled out. Thus, the majority strongly agree (SS) and agrees (S) with a percentage of 92.15 percent, while those who disagree (KS) and disagree (TS) are only around 7.84 percent. According to the statistical results of the distribution of responses, the development plan The sports center infrastructure on the UNIPA Campus has a high tendency to pay attention to environmental aspects following the development plan's concept, namely a green campus.
\end{abstract}

KEYWORDS: Public perception, statistic analysis, green campus, Papua University, Manokwari City

\section{INTRODUCTION}

The University of Papua is one of eastern Indonesia's fastest growing State Universities. On November 3, 2000, the President of the Republic of Indonesia issued Decree Number 153 of 2000, which legalized the establishment of this university. Amban Village, Manokwari Regency, West Papua Province is 
Vol. 4, Issue.6, Nov-Dec 2021, p no. 40-62

home to the University of Papua's (UNIPA) main campus. The University of Cenderawasih's Faculty of Agriculture has created UNIPA. University of Papua evolved through three stages: the FPPK UNCEN period (1964-1982), the UNCEN FAPERTA period (1982-2000), and the UNIPA period (2000-present). According to data from the Higher Education Database (PDDIKTI), the number of permanent students and lecturers at the University of Papua in the 2019/2020 Academic Year was 14,093 and 518, respectively. With an increasing number of students and lecturers each year, UNIPA requires facilities and infrastructure to develop human resources for every entrepreneurship potential of students and the community surrounding the University of Papua.

Manokwari Regency has a total area of 4,863.32 $\mathrm{km} 2$ and is divided into 9 sub-districts, 164 villages and urban villages. It is located at a latitude of $0.15 \mathrm{o}-3.25 \mathrm{o} \mathrm{S}$ and a longitude of $132.35 \mathrm{o}-134.45 \mathrm{o}$. The total population in 2018 was 168,852 (BPS 2018), with West Manokwari District having the highest population (94,054 people). West Manokwari District covers an area of $237 \mathrm{~km} 2$, with West Manokwari Village serving as the district capital. West Papua Province's development is based on the Sustainable Development Goals, namely development that meets the needs of the current generation without jeopardizing future generations' ability to meet their own needs that are adapted to local conditions and uniqueness. That in order to ensure the survival of indigenous Papuans on their own land and the people of Indonesia in general, it is necessary to use natural resources wisely and preserve the environment in order to improve the standard of living and welfare of the people in West Papua Province. It is carried out as part of a comprehensive and sustainable development process to improve the standard of living and welfare of the people in West Papua Province through the economic sector/sector that utilizes natural resources.

To date, facility and infrastructure planning has been developed with a convenience approach, which means that facility and infrastructure planning is always based on the easy reach between residence and various life-supporting elements, both in terms of service needs, relaxing, and going to work in and around the area. Thus, facility and infrastructure planning is always based on the convenience (accessibility) approach, which is then supplemented with infrastructure availability and comfort factors (aminity) [1]- [4].

The University of Papua's Sport Center Infrastructure Development Plan is a must-have. This infrastructure is expected to indirectly support the achievement of teaching and learning for students who are supported by physical health in order to support the achievement of UNIPA's educational vision. The number of students at UNIPA is increasing in tandem with the number of study programs and faculties. The 2017/2018 academic year had 502 students and 13,447 lecturers, respectively, while the 2018/2019 academic year had 8,018 students. This increase in the number of students necessitates adequate infrastructure for the aforementioned activities. The residents who live in the vicinity of the work site are a diverse group. They are from a variety of ethnic groups, including Biak, Sorong, Serui, Manokwari, Ambonese, Javanese, Bugis/Makassar, and others. The majority of them are staff members and their families who live in official houses on UNIPA land, while others are private/private 
Vol. 4, Issue.6, Nov-Dec 2021, p no. 40-62

land. The community responded in a variety of ways to the plan to build this sports infrastructure. People who do not live-in direct contact with the project site have a positive perception of the development of sports infrastructure because they believe that more adequate sports infrastructure will be available. Meanwhile, some residents who live in close proximity to the construction site have expressed their concerns. The question is whether the development includes the house they've been living in all this time. as well as the impact that the construction process or construction period may have on their comfort at that time.

The infrastructure development plan's project site is located on the UNIPA Campus in the Amban Village area of West Manokwari District. There are at least six RTs (Rukun Tetangga) in the RW 1 area that have direct access to the project site: RTs 1, 5, 6, 7, and 8, as well as RT 01/RW 04. Amban Village has an environmental unit (SLS) of 10 Rukun Warga (15.38\%) and 33 Rukun Tetangga (14.67\%) of all SLS in West Manokwari District, according to BPS Manokwari District in 2018. Amban Village occupies $36.27 \mathrm{~km} 2$ (15.29\%) of the total area of the West Manokwari District, which totals $237.24 \mathrm{~km} 2$.

A green campus, also known as an environmentally friendly campus, is defined as a concept that prioritizes the practice of long-term environmental protection, management, and preservation efforts in educational institutions. [5]- [10]. The layout and condition of campus facilities and infrastructure, energy utilization and global warming anticipation, integrated waste management, efficient use of water, use and creation of environmentally friendly transportation facilities, and environmentally sound education are all criteria for creating an environmentally sound campus. This concept has begun to be widely used on various campuses in Indonesia. [11], [12], [21], [13]- [20]. The importance of environmental sustainability in higher education has grown in recent years. The University of Papua (UNIPA) Manokwari is one of the universities that has already expressed a desire to play an active role in national and global sustainable development.

The UNIPA campus will be the site of green campus research, particularly in the areas of sports center facilities and infrastructure, as well as environmental and infrastructure arrangements. The goal of this study is to determine the scoring method based on the UI GreenMetric, investigate the application of the green campus concept in environmental and infrastructure planning, and assess the campus's willingness and availability to implement the concept of sustainable development. [22]-[29]. This research is expected to contribute to the realization of UNIPA's vision, particularly in the development of sports center space, facilities, and infrastructure. The construction of sports center facilities and environmental area arrangement is a function and benefit of increasing human resources in the fields of sports and entrepreneurship, as well as the arrangement of sustainable environmental buildings and infrastructure. According to PERPRES NO 64 OF 2018, concerning the Development of Sport Center Infrastructure at the University of Papua in Manokwari Regency, West Papua Province, and INPRES NO 9 YEAR 2017, concerning the Acceleration of Welfare Development in Papua and West Papua Provinces, that in the context of accelerating Welfare Development in West Papua Province in the 
Vol. 4, Issue.6, Nov-Dec 2021, p no. 40-62

Health Sector and Education, local economic development, basic infrastructure, digital infrastructure, and connectivity to the internet.

To improve the quality of education on the UNIPA campus, particularly in the field of sports, it is thought necessary to build a Sport Center building and a student building to support extracurricular activities on the UNIPA campus. In the construction of the Sport Center Facility, careful planning in harmony and harmony, in accordance with sustainable and detailed development, is required. Structuring buildings and the environment is a development activity that consists of the technical planning process, construction implementation, as well as utilization activities, to plan, implement, repair, develop, or preserve environmental buildings and infrastructure in specific areas in accordance with the principles of optimal use of space and control of buildings and the environment.

So that it can be implemented in realizing the structure of the Sport Center infrastructure and environment and infrastructure that is livable, self-identified, productive, and sustainable, and contains the main material provisions for building and environmental programs, general plans and design guidelines, investment plans, planning control provisions, and empowerment activities, supervision aimed at realizing the effectiveness of the actors' roles in organizing b (government, UNIPA Campus, communities and the business world) and implementation of sports facilities and with a land area of 457.2 $\mathrm{Ha}$ in the UNIPA area in the Regency.

\section{METHOD}

\subsection{Study Location}

The study lasted eight months, beginning in August 2020 and ending in March 2021. As shown in Figure 1, the research was carried out at the University of Papua (UNIPA) Campus Environment, Amban Village, West Manokwari District, Manokwari Regency, West Papua Province.

\subsection{Study Methods}

The quantitative method was used. The data obtained is secondary data; this planning process necessitates the use of various data and information collection techniques in the field. Interview techniques, document studies, field studies, documentation studies, and surveys/observations/direct observations are just a few of the techniques that can be used and are relevant. 


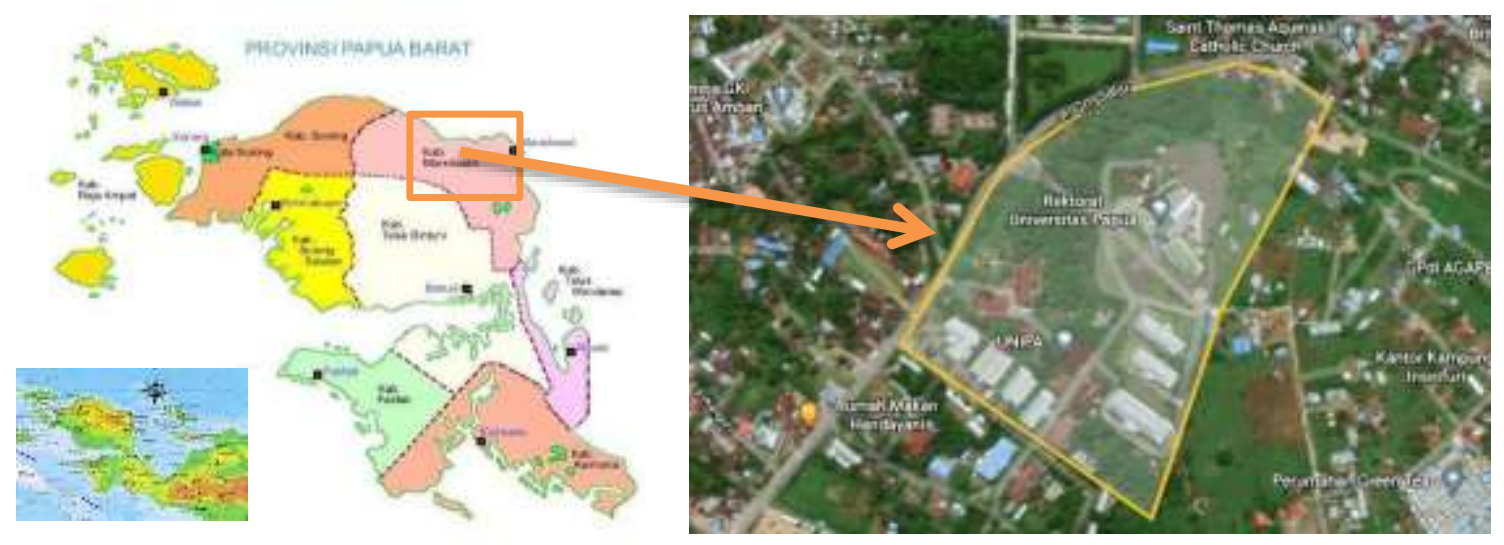

Figure 1. Study Location

\subsection{Data Collection}

The techniques or methods used by researchers to collect data are referred to as data collection methods. Data collection was carried out in order to obtain the information required to meet the research objectives. Meanwhile, a data collection instrument is a tool for gathering data. Because it is a tool, data collection instruments can take the form of check lists, questionnaires, interview guidelines, cameras for taking photos or recording images, and so on. Data collection methods are classified based on the type of data, which is classified as primary or secondary data, so the data collection in this study is classified as primary or secondary data collection.

a. From primary sources Respondents' primary data was gathered through the distribution of questionnaires or direct interviews with contracting companies (associations), the Environment Agency, the Public Works Agency, and the Bappeda of Manokwari Regency. Respondents are Project Managers and/or Project Implementers who are involved in building projects on the UNIPA Campus and have more than 5 years of experience managing building projects. The following methods can be used to obtain primary data:

\section{1) Questionnaire}

Questionnaires are used to collect information from research participants. The questionnaire includes questions and statements about the research objectives. Each variable was assigned a score by the respondents.

\section{2) Interview}

Interviews were conducted to elicit additional information and double-check respondents' responses to the questionnaire's questions/statements. This is done to reduce the researcher's and respondent's bias toward the questionnaire's questions/statements. 
Vol. 4, Issue.6, Nov-Dec 2021, p no. 40-62

\section{3) Field observation}

Field observation is a survey that is carried out by directly observing the phenomena or characteristics of the parameters under consideration (Hasan, 2001). Observations were made in order to supplement information and data that could not be obtained from secondary surveys. This technique is used to gather information in the form of existing conditions related to the implementation of a green campus on the UNIPA campus in Manokwari Regency through direct visual observations made at the research site.

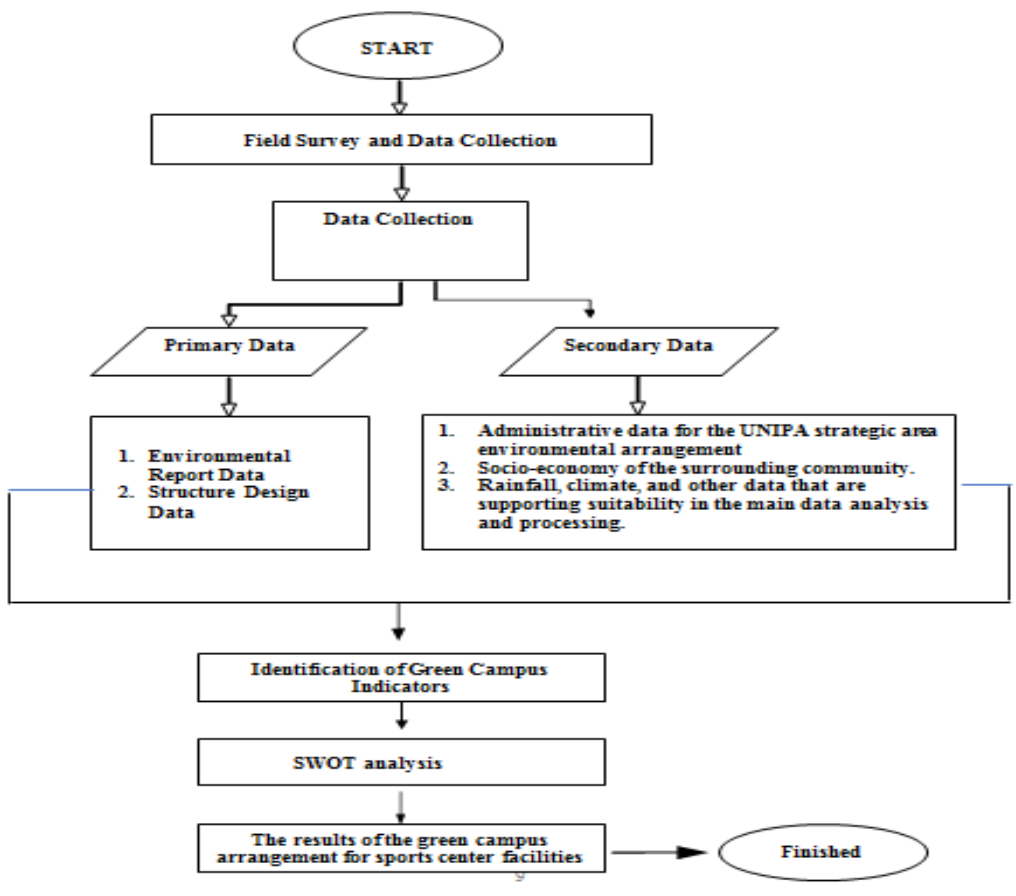

Figure 2. Research flow chart

Table 1. Types of primary data

\begin{tabular}{lccclc}
\hline \multirow{2}{*}{ Data Type } & \multicolumn{3}{c}{ Data Form } & \multirow{2}{*}{ Data source } & $\begin{array}{c}\text { Data Collection } \\
\text { Technique }\end{array}$ \\
\cline { 2 - 4 } & Map & Description & Table & & - Unstructured \\
UNIPA Campus & $\mathrm{v}$ & $\mathrm{v}$ & Field & interview \\
Existing & & & observation/survey & - Observation \\
Conditions & & & & - Documentation \\
& & & Field & - Unstructured \\
The area of land & $\mathrm{v}$ & observation/survey & interview \\
that has been & & & - Observation \\
built & & & & - Documentation \\
\hline
\end{tabular}




\section{International Journal of Education and Social Science Research}

ISSN 2581-5148

Vol. 4, Issue.6, Nov-Dec 2021, p no. 40-62

\begin{tabular}{|c|c|c|c|c|c|}
\hline $\begin{array}{l}\text { Type, number } \\
\text { and location of } \\
\text { facilities \& } \\
\text { infrastructure } \\
\text { that have been } \\
\text { built }\end{array}$ & $\mathrm{v}$ & $\mathrm{V}$ & $\mathrm{V}$ & $\begin{array}{l}\text { Field } \\
\text { observation/survey }\end{array}$ & $\begin{array}{l}\text { - Unstructured } \\
\text { interview } \\
\text { - Observation } \\
\text { - Documentation }\end{array}$ \\
\hline $\begin{array}{l}\text { Percentage of } \\
\text { conformity of } \\
\text { development } \\
\text { with plan/ } \\
\text { Implementation } \\
\text { of green design }\end{array}$ & & $\mathrm{V}$ & $\mathrm{V}$ & $\begin{array}{l}\text { Field } \\
\text { observation/survey }\end{array}$ & $\begin{array}{l}\text { - Unstructured } \\
\text { interview } \\
\text { - Observation } \\
\text { - Documentation }\end{array}$ \\
\hline $\begin{array}{l}\text { Compliance } \\
\text { with existing } \\
\text { environmental } \\
\text { documents }\end{array}$ & & $\mathrm{V}$ & $\mathrm{v}$ & $\begin{array}{l}\text { Field } \\
\text { observation/survey }\end{array}$ & $\begin{array}{l}\text { - Unstructured } \\
\text { interview } \\
\text { - Observation } \\
\text { - Documentation }\end{array}$ \\
\hline $\begin{array}{l}\text { Implementation } \\
\text { of } \\
\text { Environmental } \\
\text { Management } \\
\text { and Monitoring }\end{array}$ & & $\mathrm{V}$ & $\mathrm{v}$ & $\begin{array}{l}\text { Field } \\
\text { observation/survey }\end{array}$ & $\begin{array}{l}\text { - Unstructured } \\
\text { interview } \\
\text { - Observation } \\
\text { - Documentation }\end{array}$ \\
\hline $\begin{array}{l}\text { Equipment used } \\
\text { in the } \\
\text { construction } \\
\text { process }\end{array}$ & & $\mathrm{V}$ & $\mathrm{V}$ & $\begin{array}{l}\text { Field } \\
\text { observation/survey }\end{array}$ & $\begin{array}{l}\text { - Unstructured } \\
\text { interview } \\
\text { - Observation } \\
\text { - Documentation }\end{array}$ \\
\hline
\end{tabular}

\section{b. Secondary data}

Secondary data is information in the form of written texts or documents that has been processed and presented by a third party (Umar, 2000). A literature review was used to gather secondary data, specifically theories about risks and opportunities, as well as the methods used to discuss these issues. The risk and opportunity variables, as well as the probability impact matrix theory, are to be obtained by the journals. Meanwhile, institutions interested in this research, as well as activity-related agencies (PU, DLH, Bappeda, Health Office, Education Office), and construction service associations, will collect data on contractors involved in the construction of building projects on the UNIPA campus. 
Vol. 4, Issue.6, Nov-Dec 2021, p no. 40-62

Table 2. Types of Secondary Data

\begin{tabular}{|c|c|c|c|c|c|}
\hline \multirow[b]{2}{*}{ Jenis Data } & \multicolumn{3}{|c|}{ Bentuk Data } & \multirow[b]{2}{*}{ Sumber Data } & \multirow{2}{*}{$\begin{array}{c}\text { Teknik } \\
\text { Pengambilan } \\
\text { Data }\end{array}$} \\
\hline & Peta & Uraian & Tabel & & \\
\hline $\begin{array}{l}\text { Type, quantity, and } \\
\text { location of the } \\
\text { planned facilities and } \\
\text { infrastructure }\end{array}$ & $\mathrm{v}$ & $\mathrm{v}$ & $\mathrm{v}$ & $\begin{array}{l}\text { Executing } \\
\text { Contractor }\end{array}$ & $\begin{array}{l}\text { Institutional } \\
\text { Survey }\end{array}$ \\
\hline $\begin{array}{l}\text { UNIPA campus green } \\
\text { design concept }\end{array}$ & & $\mathrm{v}$ & & $\begin{array}{l}\text { Executing } \\
\text { Contractor }\end{array}$ & $\begin{array}{c}\text { Literature and } \\
\text { Institutional } \\
\text { Survey }\end{array}$ \\
\hline $\begin{array}{l}\text { Procedures and stages } \\
\text { of the UNIPA campus } \\
\text { green design } \\
\text { development }\end{array}$ & & $\mathrm{v}$ & & $\begin{array}{l}\text { Executing } \\
\text { Contractor }\end{array}$ & $\begin{array}{c}\text { Literature and } \\
\text { Institutional } \\
\text { Survey }\end{array}$ \\
\hline Number of Students & & $\mathrm{v}$ & $\mathrm{v}$ & UNIPA campus & Literature \\
\hline UNIPA Campus Area & $\mathrm{v}$ & $\mathrm{v}$ & $\mathrm{v}$ & UNIPA campus & Literature \\
\hline $\begin{array}{l}\text { Campus Land Use } \\
\text { Plan/Campus Master } \\
\text { Plan }\end{array}$ & $\mathrm{v}$ & $\mathrm{v}$ & $\mathrm{v}$ & UNIPA campus & Literature \\
\hline $\begin{array}{l}\text { Environmental } \\
\text { Document }\end{array}$ & $\mathrm{v}$ & $\mathrm{v}$ & $\mathrm{v}$ & $\begin{array}{l}\text { Executing } \\
\text { Contractor }\end{array}$ & $\begin{array}{c}\text { Literature and } \\
\text { Institutional } \\
\text { Survey }\end{array}$ \\
\hline
\end{tabular}

\subsection{Sampling}

The population/sample in this study consists of building projects that are being or have been constructed on the UNIPA campus. The company (contractor) involved in the implementation of the building project on the UNIPA Campus is the subject of this investigation. While the respondents are Project Managers and/or Implementers involved in the implementation of building projects, whether they are members of construction service associations or not, they have more than 5 years of experience and are decision makers in their respective organizations. The sampling method employs purposive sampling (including non-probability sampling), which is better suited for qualitative research or research that does not generalize (Sugiyono 2004; 96), and respondents are chosen from specific circles (a sample determined by the respondent), given that the object of this research is a specific object. The sample in this study is a population of contractor companies on the UNIPA campus, whether they are members of the association or not. 
Vol. 4, Issue.6, Nov-Dec 2021, p no. 40-62

\section{RESULTS AND DISCUSSION}

\subsection{Overview of Study Sites}

The Papua State University (UNIPA) Campus, located at Jln. Amban Snow Mountain, Manokwari, West Papua, is the research location for the construction of sports center infrastructure. Administratively, the activity takes place in Amban Village, West Manokwari District, Manokwari Regency, West Papua Province. The activity's location is bounded to the north by UNIPA lecturers' housing and villages, to the south by the old rectorate and the forestry faculty, to the east by lecturer housing, and to the west by Jalan Flamboyan. Table 3 shows the geographic coordinates of the University of Papua Sports Infrastructure Development business and/or activity.

Table 3. The coordinates of sports infrastructure activities location

\begin{tabular}{|c|c|c|}
\hline Boundary & \multicolumn{2}{|c|}{ Coordinates } \\
\hline $\bar{A}$ & $0^{\circ} 49^{\prime} 50.63 " \mathrm{~S}$ & $134^{\circ} 4^{\prime} 04.25^{\prime \prime} \mathrm{E}$ \\
\hline B & $0^{\circ} 49^{\prime} 50.54 " \mathrm{~S}$ & $134^{\circ} 3^{\prime} 57.29^{\prime \prime} \mathrm{E}$ \\
\hline $\mathrm{C}$ & $0^{\circ} 49^{\prime} 48.18^{\prime \prime S}$ & $134^{\circ} 3^{\prime} 57.24^{\prime \prime} \mathrm{E}$ \\
\hline $\mathrm{D}$ & $0^{\circ} 49^{\prime} 48.19^{\prime \prime} \mathrm{S}$ & $134^{\circ} 3^{\prime} 59.70^{\prime \prime} \mathrm{E}$ \\
\hline $\mathrm{E}$ & $0^{\circ} 49^{\prime} 45.62^{\prime \prime} \mathrm{S}$ & $134^{\circ} 3^{\prime} 59.75^{\prime \prime} \mathrm{E}$ \\
\hline $\mathrm{F}$ & $0^{\circ} 49^{\prime} 45.67^{\prime \prime S}$ & $134^{\circ} 4^{\prime} 02.24^{\prime \prime} \mathrm{E}$ \\
\hline G & $0^{\circ} 49^{\prime} 47.87^{\prime \prime S}$ & $134^{\circ} 4^{\prime} 02.24^{\prime \prime} \mathrm{E}$ \\
\hline $\mathrm{H}$ & $0^{\circ} 49^{\prime} 47.87^{\prime \prime S}$ & $134^{\circ} 4^{\prime} 04.19^{\prime \prime} \mathrm{E}$ \\
\hline I & $0^{\circ} 49^{\prime} 46.84 " \mathrm{~S}$ & $134^{\circ} 4^{\prime} 04.19^{\prime \prime} \mathrm{E}$ \\
\hline $\mathrm{J}$ & $0^{\circ} 49^{\prime} 46.84 " \mathrm{~S}$ & $134^{\circ} 4^{\prime} 11.54^{\prime \prime} \mathrm{E}$ \\
\hline K & $0^{\circ} 49^{\prime} 49.90 " \mathrm{~S}$ & $134^{\circ} 4^{\prime} 11.54^{\prime \prime} \mathrm{E}$ \\
\hline $\mathrm{L}$ & $0^{\circ} 49^{\prime} 49.90^{\prime \prime} \mathrm{S}$ & $134^{\circ} 4^{\prime} 04.23^{\prime \prime} \mathrm{E}$ \\
\hline
\end{tabular}

The construction of this sports infrastructure is expected to have a positive impact on all members of the UNIPA academic community as well as the community surrounding UNIPA. West Manokwari District has a population of 50,443 people and a population density per $\mathrm{km} 2$ of 396.45 people.

\subsection{Land Measurement of the UNIPA Campus Sport Center}

The plan for the development of sports infrastructure will make use of 4.3 ha of land owned by the University of Papua. This area is made up of 0.39 ha of buildings, 3.25 ha of sports fields and parking lots, and 0.8 ha of green open space. The spectator stands that will be built will hold between 2,400 and 2,500 people. This sports facility also has a parking area that can accommodate 105 four-wheeled vehicles and 182 two-wheeled vehicles. The following are the specifics of the facilities and infrastructure that will be built in that location: 
Vol. 4, Issue.6, Nov-Dec 2021, p no. 40-62

\section{a. Main Gate and Corridor}

The main sports infrastructure gate is located on Jalan Gunung Snow in Amban Manokwari, directly in front of the rectorate gate. A corridor will be built between the main gate and the sports facilities. The length of this corridor is 160 meters, and it will lengthen and widen the road to the old rectorate. The road will be divided into two lanes with a width of 6 meters each, with a pedestrian walkway between the two roads with a width of 12.5 meters.

\section{b. Soccer Field and Athletic Track}

The dimensions of the soccer field to be built are $117 \mathrm{~m} \times 73 \mathrm{~m}$. Natural grass will be used on this soccer field. This soccer field also has a drainage system to prevent water puddles when it rains. This field is also outfitted with a grass watering system. For the Athletics Track, 1 track track with a track length of $400 \mathrm{~m}, 4$ units of long jump and teeter-totter, 2 units of shot put track, 1 unit for discus throwing, 1 unit for martyrdom and discus throwing, 2 javelin throwing, 2 high jumps, 4 pole vaults, and 1 obstacle course will be built. The Sandwich system running track layer has a thickness of $14 \mathrm{~mm}$ and is made of polyurethane, recycled SBR rubber granules, and EPDM Powdered Rubber.

\section{c. Audience Stand}

The spectator stands, which measure $86 \mathrm{~m} \times 19.5 \mathrm{~m}$, are built on the football field's edge. The tribune has two floors and a roof, and it can accommodate up to 2400 spectators. A dressing room and restrooms are also available in the spectator stands.

\section{d. Softball Court}

The softball field is $3846.5 \mathrm{~m} 2$ in size. This field, like a football field, will use natural grass, specifically Zoysia Japonica grass, and will be outfitted with a drainage system as well as a grass watering system.

\section{e. Tennis court}

The outdoor tennis court constructed at the Papua University sports infrastructure measures $36 \mathrm{~m} \mathrm{x}$ $10.5 \mathrm{~m}$. There are two tennis courts on the property.

\section{f. Volleyball court}

The University of Papua's sports infrastructure will also include two outdoor volleyball courts measuring $18 \mathrm{~m} \times 9 \mathrm{~m}$.

\section{g. Parking lot}

In addition to sports fields, sports infrastructure will include parking lots. The parking lot is divided into two sections: a car park and a motorcycle parking lot. The $3375 \mathrm{~m} 2$ car park will be able to accommodate 105 four-wheeled vehicles. Meanwhile, the two-wheeler parking lot is $600 \mathrm{~m} 2$ in size and can accommodate up to 182 two-wheeled vehicles. 


\section{h. Supporting Facilities}

The wastewater treatment plant from the toilet will flow into the Bio Septic before entering the infiltration well. As shown in Fig. 1, the dimensions of the Bio Septic tank to be built are $2 \mathrm{~m} \times 1.2 \mathrm{~m}$ $\mathrm{x} 1.5 \mathrm{~m}$. The bio septic tank water will be pumped into the infiltration well. One-meter-diameter infiltration wells will be built. The rest of the toilets will use the same design and color scheme. The drainage channel is sealed with a concrete pipe $30 \mathrm{~cm}$ in diameter, which is then connected to the main drainage channel $0.7 \mathrm{~m} \times 0.6 \mathrm{~m}$. Ground tanks will be constructed to hold water sourced from clean water. Clean water is distributed to the ground by flowing from above through a 3/4" PVC pipe to a rainwater storage area (Ground tank). The UNIPA clean water system provides clean water to meet the needs of sports infrastructure. In addition to water from the UNIPA clean water system, rainwater downloads can be used to obtain clean water.

Table 4. Area of Sports Infrastructure Building

\begin{tabular}{|l|r|}
\hline \multicolumn{1}{|c|}{ Types of Sports Infrastructure } & Building area $\mathbf{( m}^{\mathbf{2}} \mathbf{)}$ \\
\hline Main Gate & 15 \\
\hline Corridor & 4589,1 \\
\hline Plaza & 1931 \\
\hline Tribune Building & 1677 \\
\hline $\begin{array}{l}\text { Support Building (Toilet, Male \& Female } \\
\text { Changing Room) }\end{array}$ & 200 \\
\hline Prayer room & 90 \\
\hline Basketball Court (2 units) & 960 \\
\hline Volleyball Court (2 units) & 323,5 \\
\hline Soccer Field and Athletic Track & 15.483 \\
\hline Tennis Court (2 units) & 1.350 \\
\hline Softball Field & $3.846,5$ \\
\hline Car Parking Area & 3.375 \\
\hline Motorcycle Parking Only & 600 \\
\hline Green open space & 8.560 \\
\hline \multicolumn{1}{|c|}{ Total Area } & 43.000 \\
\hline
\end{tabular}

\subsection{Description of the Current State and Future Development Plans for Sport Center Facilities on the UNIPA Campus in the Setting and Infrastructure Category}

The University of Papua's Sports Infrastructure Development Plan is an absolute necessity that must be realized. This infrastructure is expected to indirectly support the achievement of teaching and learning for students who benefit from physical health in an effort to support the achievement of Unipa's educational vision. The number of students at UNIPA is growing in tandem with the number of study programs and faculties. In the 2017/2018 academic year, there were 502 students and lecturers and 13,447 students, while the 2018/2019 school year had 8,018 students. 
Vol. 4, Issue.6, Nov-Dec 2021, p no. 40-62

This increase in the number of students undoubtedly necessitates adequate infrastructure for the aforementioned activities. The infrastructure development plan's project site is the Unipa Campus in the Amban Village area of West Manokwari District. There are at least six neighborhood association (RT) in the citizens association (RW-1) area that have direct contact with the project site, namely RTs 1, 5, 6, 7, and 8, as well as RT-01/RW-04. Amban Village has an environmental unit (SLS) of 10 Rukun Warga (15.38\%) and 33 RT (14.67\%) of all SLS in West Manokwari District, according to BPS Manokwari District in 2018. Amban Village occupies $36.27 \mathrm{~km} 2$, or $15.29 \%$ of the total area of the West Manokwari District, which totals 237.24 km2.

The study site, located in East Manokwari, is physiographically part of the Uplifted Coral Reef and Gisik Reef unit. The research site is a raised coral reef that forms smooth, broad hills that are characteristically wide and reach altitudes of up to 290 meters above sea level. Based on field observations, the type of rock at the business/activity location is sedimentary rock (limestone) with sand-sized grains and a top soil thickness of 0.5-2 m, classifying it as hydrological group A. The activity location's topography has a slope ranging from $2 \%$ to $8 \%$. Meanwhile, the land cover is dominated by forest and some clearings. In addition, the run-off coefficient values for soil group $\mathrm{A}$ in various conditions and their management are discussed.

Based on the results of the activity location overlay and the 2013-2033 Regional Spatial Plan (RTRW) of Manokwari Regency Number: 19 of 2013, as well as the Spatial Layout Recommendation letter from BAPPEDA Manokwari Regency No. 648/178, it can be concluded that the entire site of the University of Papua Sports Infrastructure Development project covering an area of an acre and a half is suitable. According to data from the Manokwari Meteorology, Climatology, and Geophysics Agency (BMKG) Station, the average rainfall in Manokwari is $2448.8 \mathrm{~mm} /$ year, with 16 rainy days per month, indicating that the rainfall intensity is high.

Basketball Courts, Volleyball Courts, Soccer Fields, Athletic Tracks, Tennis Courts, and Softball Fields will be used by the University of Papua's academic community to increase talent and demand in various sports. Sports activities, sporting events, and other activities that use this infrastructure will take place in the Sports Facilities area. It is estimated that if this infrastructure is operational, it will be able to accommodate approximately 2400 visitors.

The sport center's location on the UNIPA campus poses no challenges because the available land is ample. Based on the findings of the observations, it is clear that the location of the UNIPA Campus Sport Center has a scattering of green open space that has not been well organized. The majority of existing green open space is still in its natural state or has not been processed. This demonstrates that the layout of the sports center on the UNIPA Campus was well planned. Where there is still a lot of undeveloped land planned for the construction and development of sports center infrastructure, such as sports fields, parking lots, parks, changing rooms, and other public facilities that must be available based on standard needs in a sports center area. 
Vol. 4, Issue.6, Nov-Dec 2021, p no. 40-62

\subsection{Analysis of the Implementation of Green Campus Indicators in the UNIPA Campus Sport Center Infrastructure Development Plan}

The planning, implementation, and existing conditions have met the standard, according to the results of primary and secondary surveys related to the construction of sports center facilities on the UNIPA Campus. This is demonstrated by the findings of an analysis of various indicators used as measuring tools.

The green campus concept that must be implemented must address all aspects of campus life. Yes, based on the concept, the plan to construct a sports center on the UNIPA Campus is already viable. It is clear that six elements must be implemented in order to create a green campus: smart energy, smart mobility, smart water, smart public services, smart building, and smart rubbish. [22].

\section{Smart Energy}

Smart energy is a concept in which campus needs are managed in a smart and renewable manner. A monitoring system in time units is required so that energy needs can be audited properly so that the campus's energy needs can be managed properly.

\section{Smart Mobility}

Vehicle management and student mobility are critical components of achieving a green campus. Students have mobility issues at UNIPA because of the campus's large size. A pedestrian route should also be established on campus to familiarize students with walking. Not only to reduce pollution, but also to start a healthy lifestyle. It is also necessary to monitor and manage vehicle traffic around campus in order to maintain good mobility. Students will use short and fast routes that can be accessed by bicycle and on foot more than motorbikes that require longer detours.

\section{Smart Water}

Water is one of the most basic human needs, particularly on college campuses. Good water management is required to implement the green campus concept on the UNIPA campus. It is necessary to provide clean, ready-to-drink water faucets in every park and public space in UNIPA. This is done so that students aren't too lazy to keep buying bottled water, the packaging of which is usually thrown away carelessly. Students benefit from the availability of safe drinking water that is ready for consumption. This can contribute to the development of UNIPA's green campus as an environmentally friendly and green campus.

\section{Smart Public Services}

The importance of public services in achieving a green campus cannot be overstated. The concept of smart public services refers to the integration of all public services on the UNIPA campus. 
Vol. 4, Issue.6, Nov-Dec 2021, p no. 40-62

\section{Smart Building}

A green campus will not be realized unless the building itself is environmentally friendly.

\section{Smart Rubbish}

Waste management is critical in any environment, but especially on a busy campus with lots of activities. The first step is to teach students to always separate waste by category. Following that, each part of the campus has an integrated waste management operational standard. Compost can be made from organic plant waste. Inorganic waste is disposed of and processed in accordance with its intended use. [18]

The presence of a campus, which is a place where technology, science, and innovation are enforced, qualifies the campus as a small part of the global community at the local level that should participate in the fight to overcome the effects of climate change and sustainable development within its environmental scope. [17].

The green campus program is not easy to implement; campus administration and students must collaborate to make the program a reality. The role of campus management in implementing the green campus program is critical, so the level of understanding of campus management of the green campus concept must be taken into account. In addition to the campus administration's understanding of the green campus concept, it is critical to pay attention to the conditions and environment surrounding the campus being led. This lack of understanding can increase the likelihood of problems when planning activities, implementing policies, or directing green campus programs [17], [18]. Based on this, we require a standard that can be used as a reference and motivation for management to increase its effectiveness in the success of the green campus program in the Sport Center Infrastructure Development Plan on the UNIPA Campus.

According to the findings of primary data collection, there are several challenges that must be overcome when implementing a green campus in the Sport Center Infrastructure Development Plan on the UNIPA Campus. These obstacles are as follows: The monitoring function is still weak, resulting in the implementation of the green campus concept not running continuously; a lack of commitment to creating a green campus; a lack of understanding among campus users; weak campus leadership policies related to green campuses; being under-socialized; having a limited sense of humour.

\subsection{Scoring Based on UI Green Metric Settings and Infrastructure Criteria}

Following the measurement of all existing indicators, a scoring assessment is performed. A fixed value range is required when scoring. Table 4 shows the range of values that will be used in this study. The maximum value obtained from the UI GreenMetric standard is further subdivided into several assessment ranges with varying scoring standards. 
Vol. 4, Issue.6, Nov-Dec 2021, p no. 40-62

Meanwhile, Table 3 shows the final results of the indicator calculations in the UI GreenMetric setting and infrastructure criteria.

\subsection{Analysis of the Layout and Facilities of the Sport Center}

Data analysis is then performed based on the results of processing measurement data, observations, and interviews, as shown in Table 8.

Table 5. Implementation of the Green Campus Plan for the Development of Sport Center Infrastructure on the UNIPA Campus

\begin{tabular}{|l|c|c|c|}
\hline \multicolumn{1}{|c|}{ Description } & Good & Moderate & Bad \\
\hline Konsep Green Campus & $\sqrt{ }$ & $\sqrt{ }$ & \\
\hline $\begin{array}{l}\text { Pengelolaan Dan Pemantauan Pelaksanaan } \\
\text { Pembangunan }\end{array}$ & & $\sqrt{ }$ & \\
\hline $\begin{array}{l}\text { Penggunaan Alat-Alat Yang Ramah } \\
\text { Lingkungan }\end{array}$ & & $\sqrt{ }$ & \\
\hline $\begin{array}{l}\text { Pengelolaan Dan Pemantauan Dampak Yang } \\
\text { Ditimbulkan Dari Kegiatan Pembangunan }\end{array}$ & $\sqrt{ }$ & & \\
\hline $\begin{array}{l}\text { Jumlah Sarana Dan Prasarana Yang Tersedia } \\
\text { Mendukung Konsep Green Campus }\end{array}$ & $\sqrt{ }$ & & \\
\hline $\begin{array}{l}\text { Jumlah sarana dan prasarana kampus sudah } \\
\text { memadai dengan luas lahan dan jumlah } \\
\text { pengguna kampus }\end{array}$ & $\sqrt{ }$ & & \\
\hline $\begin{array}{l}\text { Prosesntase RTH yang tersedia sudah sesuai } \\
\text { dengan ketetapan }\end{array}$ & $\sqrt{ }$ & & \\
\hline $\begin{array}{l}\text { Kampus tidak pernah bermasalah dengan } \\
\text { lingkungan sekitar }\end{array}$ & $\sqrt{ }$ & & \\
\hline $\begin{array}{l}\text { Kampus menyediakan anggran rutin untuk } \\
\text { perawatan dan pemeliharaan sarana dan } \\
\text { prasarana }\end{array}$ & & & \\
\hline $\begin{array}{l}\text { Lokasi kampus sudah sesuai dengan } \\
\text { peruntukan lahan }\end{array}$ & \begin{tabular}{l} 
\\
\hline $\begin{array}{l}\text { Rasio minimum luas lahan konsep green } \\
\text { campus terhadap luasan lahan keseluruhan }\end{array}$
\end{tabular} & & \\
\hline
\end{tabular}

Source: Analysis Results, 2021 
Vol. 4, Issue.6, Nov-Dec 2021, p no. 40-62

Table 6. Scoring Method Scoring Range

\begin{tabular}{|c|c|c|c|c|c|}
\hline $\begin{array}{c}\text { Indicator } \\
\text { Code }\end{array}$ & Indicator & Standard & $\begin{array}{c}\text { Rating Score for } \\
\text { Specific Ratio } \\
\text { Range }\end{array}$ & $\begin{array}{c}\text { Maximum } \\
\text { Value }\end{array}$ & Explanation \\
\hline SI 1 & $\begin{array}{l}\text { Ratio of open } \\
\text { space area to } \\
\text { total area }\end{array}$ & $\begin{array}{l}40 \% \text { of the } \\
\text { campus area }\end{array}$ & $\begin{array}{l}0=0 \% \\
30=0,01 \%- \\
7,77 \% \\
60=7,78 \%- \\
15,54 \% \\
90=15,55 \%- \\
23,31 \% \\
120=23,32 \%- \\
31,08 \% \\
150=31,09 \%- \\
38,85 \% \\
180=38,86 \%- \\
46,62 \% \\
210=46,63 \%- \\
54,39 \% \\
240=54,40 \%- \\
62,16 \% \\
270=62,17 \%- \\
70,00 \% \\
300=>70,00 \%\end{array}$ & 300 & $\begin{array}{c}\text { The } \\
\text { maximum } \\
\text { value is } \\
\text { obtained } \\
\text { when the } \\
\text { KDB is low, } \\
\text { which is } 70 \%\end{array}$ \\
\hline SI 2 & $\begin{array}{l}\text { The ratio of } \\
\text { the area of } \\
\text { open space to } \\
\text { the total } \\
\text { population of } \\
\text { universities }\end{array}$ & $4,16 \mathrm{~m}^{2}$ & $\begin{array}{l}0=0 \mathrm{~m}^{2} \\
30=0,010 \mathrm{~m}^{2}- \\
0,46 \mathrm{~m}^{2} \\
60=0,47 \mathrm{~m}^{2}- \\
0,92 \mathrm{~m}^{2} \\
90=0,93 \mathrm{~m}^{2}- \\
1,38 \mathrm{~m}^{2} \\
120=1,39 \mathrm{~m}^{2}- \\
1,84 \mathrm{~m}^{2} 150= \\
1,85 \mathrm{~m}^{2}-2,30 \mathrm{~m}^{2} \\
180=2,31 \mathrm{~m}^{2}- \\
2,76 \mathrm{~m}^{2} 210= \\
2,77 \mathrm{~m}^{2}-3,22 \mathrm{~m}^{2} \\
240=3,23 \mathrm{~m}^{2}- \\
3,68 \mathrm{~m}^{2} 270= \\
3,69 \mathrm{~m}^{2}-4,15 \mathrm{~m}^{2} \\
300=\geq 4,16 \mathrm{~m}^{2}\end{array}$ & 300 & $\begin{array}{c}\text { Standards are } \\
\text { obtained } \\
\text { based on the } \\
\text { population of } \\
\text { UNIPA } \\
\text { Campus }\end{array}$ \\
\hline
\end{tabular}


Vol. 4, Issue.6, Nov-Dec 2021, p no. 40-62

\begin{tabular}{|c|c|c|c|c|c|}
\hline SI 3 & $\begin{array}{l}\text { The area } \\
\text { covered by } \\
\text { forest plants }\end{array}$ & $\begin{array}{l}10 \% \text { of the } \\
\text { campus area }\end{array}$ & $\begin{array}{c}0=0 \% 200-20 \\
=0,01 \%-1,65 \% \\
40=1,66 \%-3,30 \\
\% 60=3,31 \%- \\
4,95 \% 80=4,96 \\
\%-6,59 \% 100= \\
6,60 \%-8,24 \% \\
120=8,25 \%- \\
9,89 \% 140=9,90 \\
\%-11,54 \% 160 \\
=11,55 \%-13,19 \\
\% 180=13,20 \% \\
-14,83 \% 200=\geq \\
14,84 \%\end{array}$ & 200 & - \\
\hline SI 4 & $\begin{array}{l}\text { Area planted } \\
\text { with plants }\end{array}$ & $\begin{array}{l}10 \% \text { of the } \\
\text { campus area }\end{array}$ & $\begin{array}{l}0=0 \% \\
20=0,01 \%-1,65 \\
\% \\
40=1,66 \%-3,30 \\
\% \\
60=3,31 \%-4,95 \\
\% \\
80=4,96 \%-6,59 \\
\% \\
100=6,60 \%- \\
8,24 \% \\
120=8,25 \%- \\
9,89 \% \\
140=9,90 \%- \\
11,54 \% 160= \\
11,55 \%-13,19 \% \\
180=13,20 \%- \\
14,83 \% 200=\geq \\
14,84 \%\end{array}$ & 200 & $\begin{array}{c}\text { With an open } \\
\text { space area of } \\
40 \%, 25.16 \% \\
\text { of the RTNH } \\
\text { area is used, } \\
\text { the RTH area } \\
\text { is } 14.84 \% \text {. }\end{array}$ \\
\hline SI 5 & $\begin{array}{l}\text { The area that } \\
\text { cannot be } \\
\text { impregnated } \\
\text { with water }\end{array}$ & $\begin{array}{l}60 \% \text { of the } \\
\text { campus area }\end{array}$ & $\begin{array}{l}0=>60,00 \% \\
30=56,67 \%- \\
60,00 \% \\
60=53,33 \%- \\
56,66 \% \\
90=50,00 \%- \\
53,32 \% 120= \\
46,67 \%-49,99 \% \\
150=43,34 \%- \\
46,66 \% 180=\end{array}$ & 300 & $\begin{array}{c}\text { Maximum } \\
\text { value is } \\
\text { obtained } \\
\text { when KDB is } \\
\text { low }\end{array}$ \\
\hline
\end{tabular}




\section{International Journal of Education and Social Science Research}

ISSN 2581-5148

Vol. 4, Issue.6, Nov-Dec 2021, p no. 40-62

\begin{tabular}{|c|c|c|c|c|c|}
\hline & & & $\begin{array}{l}40,01 \%-43,33 \% \\
210=36,68 \%- \\
40,00 \% 240= \\
33,35 \%-36,57 \% \\
270=30,00 \%- \\
33,34 \% 300=< \\
30,00 \%\end{array}$ & & \\
\hline SI 6 & $\begin{array}{l}\text { Proportion of } \\
\text { budget for } \\
\text { environmental } \\
\text { sustainability } \\
\text { activities }\end{array}$ & $\begin{array}{l}\text { (no standard } \\
\text { found) }\end{array}$ & - & 200 & - \\
\hline \multicolumn{4}{|c|}{ JUMLAH } & 1500 & \\
\hline
\end{tabular}

Table 7. Scoring results

\begin{tabular}{|c|c|c|c|c|}
\hline Category & Code & Indicator & $\begin{array}{l}\text { Existing } \\
\text { Results }\end{array}$ & Final score \\
\hline \multirow{6}{*}{$\begin{array}{c}\text { Setting and } \\
\text { Infrastructure } \\
\text { (SI) }\end{array}$} & SI 1 & $\begin{array}{c}\text { Ratio of open } \\
\text { space area to } \\
\text { total area }\end{array}$ & $55.142 \%$ & 260 \\
\hline & SI 2 & $\begin{array}{l}\text { The ratio of the } \\
\text { area of open } \\
\text { space to the total } \\
\text { population of } \\
\text { universities }\end{array}$ & $310,84 \mathrm{Km}^{2}$ & 270 \\
\hline & SI 3 & $\begin{array}{l}\text { The area } \\
\text { covered by } \\
\text { forest plants }\end{array}$ & $15,231 \%$ & 120 \\
\hline & SI 4 & $\begin{array}{l}\text { Area planted } \\
\text { with plants }\end{array}$ & $26,320 \%$ & 190 \\
\hline & SI 5 & $\begin{array}{l}\text { The area that } \\
\text { cannot be } \\
\text { impregnated } \\
\text { with water }\end{array}$ & $59,431 \%$ & 250 \\
\hline & SI 6 & $\begin{array}{l}\text { Proportion of } \\
\text { budget for } \\
\text { environmental } \\
\text { sustainability } \\
\text { activities }\end{array}$ & $>10 \%$ & 100 \\
\hline & & & & 1.190 \\
\hline
\end{tabular}


Vol. 4, Issue.6, Nov-Dec 2021, p no. 40-62

Table 8. Analysis of Layout and Infrastructure Indicators

\begin{tabular}{|c|c|c|c|}
\hline Indikator & Nilai Standar & $\begin{array}{c}\text { Hasil } \\
\text { Eksisting }\end{array}$ & Analisa \\
\hline $\begin{array}{l}\text { Ratio of open } \\
\text { space area to } \\
\text { total area }\end{array}$ & $\begin{array}{l}40 \% \text { of the } \\
\text { campus area }\end{array}$ & $55.142 \%$ & $\begin{array}{l}\text { UNIPA has a motorcycle parking area of } \\
600 \mathrm{~m} 2 \text { and a car park area of } 3,375 \mathrm{~m} 2 \text { to } \\
\text { support the plan to build a sports center in } \\
\text { the UNIPA Campus area. In addition, in } \\
\text { the open space there is still unused land } \\
\text { that should be used as a body of water, } \\
\text { green open space or RTNH }\end{array}$ \\
\hline $\begin{array}{l}\text { The ratio of the } \\
\text { area of open } \\
\text { space to the } \\
\text { total population } \\
\text { of universities }\end{array}$ & $4,16 \mathrm{~m}^{2} /$ person & $310,84 \mathrm{Km}^{2}$ & $\begin{array}{l}\text { According to secondary data, UNIPA has a } \\
\text { total population of } 11,274 \text { people and a } \\
\text { population density per } \mathrm{km} 2 \text { of } 310.84 \mathrm{~km} 2 \text {. } \\
\text { The calculation of the ratio obtained with } \\
\text { the existing population yields the best } \\
\text { results. The existing open space does not } \\
\text { meet established standards and can also be } \\
\text { used more efficiently. }\end{array}$ \\
\hline $\begin{array}{l}\text { The area } \\
\text { covered by } \\
\text { forest plants }\end{array}$ & $\begin{array}{l}10 \% \text { of the } \\
\text { campus area }\end{array}$ & $15,231 \%$ & $\begin{array}{l}\text { According to the findings of observations } \\
\text { and measurements, UNIPA is overgrown } \\
\text { with planted forest plants. The front area of } \\
\text { the Rectorate building and the campus } \\
\text { entrance dominate the planting of forest } \\
\text { plants. The distribution of plants is still } \\
\text { uneven and needs to be improved, given } \\
\text { the benefits of forest plants in the form of } \\
\text { trees, which can produce oxygen, break the } \\
\text { wind, absorb pollution, provide shade, and } \\
\text { absorb water better than grass, shrubs, or } \\
\text { shrubs. }\end{array}$ \\
\hline $\begin{array}{l}\text { Area planted } \\
\text { with plants }\end{array}$ & $\begin{array}{l}10 \% \text { of the } \\
\text { campus area }\end{array}$ & $26,320 \%$ & $\begin{array}{l}\text { This area is also referred to as green open } \\
\text { space. The distribution of green open space } \\
\text { in the UNIPA campus area sports center } \\
\text { development plan is not evenly distributed, } \\
\text { despite the fact that the results exceed the } \\
\text { standard after measurement. Unfortunately, } \\
\text { the existing green open space on campus is } \\
\text { still unable to give the impression of being } \\
\text { cool and comfortable due to uneven } \\
\text { distribution and a less shady and beautiful } \\
\text { arrangement. }\end{array}$ \\
\hline
\end{tabular}


Vol. 4, Issue.6, Nov-Dec 2021, p no. 40-62

\begin{tabular}{|c|c|c|c|}
\hline $\begin{array}{l}\text { The area that } \\
\text { cannot be } \\
\text { impregnated } \\
\text { with water }\end{array}$ & $\begin{array}{l}60 \% \text { of the } \\
\text { campus area }\end{array}$ & $59,431 \%$ & $\begin{array}{l}\text { This area includes the building area as well } \\
\text { as hardened land that is not porous and } \\
\text { cannot be planted on. According to the } \\
\text { findings, } 21.25 \text { percent of the land is } \\
\text { suitable for construction, while the } \\
\text { remaining } 38.21 \text { percent is suitable for } \\
\text { hardening. Paved land has a relatively high } \\
\text { percentage because it is still dominated by } \\
\text { paving blocks and asphalt, which cannot } \\
\text { absorb water. Despite this, there were no } \\
\text { cases of flooding or puddles on the UNIPA } \\
\text { campus because the drainage was } \\
\text { excellent.. }\end{array}$ \\
\hline $\begin{array}{l}\text { Proportion of } \\
\text { budget for } \\
\text { environmental } \\
\text { sustainability } \\
\text { activities }\end{array}$ & $\begin{array}{c}\text { (not found a } \\
\text { usable standard) }\end{array}$ & $>10 \%$ & $\begin{array}{l}\text { UNIPA has not prioritized its budget for } \\
\text { environmental sustainability activities } \\
\text { because UNIPA's priority remains } \\
\text { academic staff research and development. } \\
\text { The assessment of the budget proportion } \\
\text { indicator for environmental sustainability } \\
\text { activities cannot be assessed in this study } \\
\text { because the standard has not been obtained. }\end{array}$ \\
\hline
\end{tabular}

Source: Analysis Results, 2021

Based on the findings of the analysis, the following recommendations for the future construction of sports center infrastructure facilities for the UNIPA Campus can be made: 1) In order to support the green campus concept, the UNIPA Campus must implement new policies in the form of regulations or budgetary allocations for development, improvement, and maintenance, 2) paving with paving blocks so that water can still seep into the ground and reduce surface water, 3) providing vertical gardens and roof gardens in a variety of vacant and possible locations, 4) developing a garden concept that meets the needs of students in order to foster a sense of belonging and a desire to preserve the park's beauty and sustainability. 5) Convert unused land into green open space and RTNH.6) It is also necessary to plan evacuation routes and assembly points in Manokwari Regency, West Papua Province, which includes earthquake-prone areas.

\section{CONCLUSIONS}

Based on the findings of the analysis, the following conclusions can be drawn as the final results of the research findings:

1. Based on the results of an analysis of green campus indicators at the sports center at UNIPA, the program is now being implemented and is progressing well. Only a few indicators need to be improved 
Vol. 4, Issue.6, Nov-Dec 2021, p no. 40-62

in the construction of a sports center at UNIPA, such as: Pengelolaan dan Pemantauan Pelaksanaan Pembangunan, the use of high-quality equipment, and the provision of anggran routes for maintenance and development. In the meantime, other indicators have improved their performance when used in the lab.

2. Based on the results of the SWOT analysis, the strategy for structuring the environment and green campus infrastructure at the UNIPA campus sports center infrastructure must pay attention to the threats that may arise as a result of the construction of a sports center on the UNIPA campus, such as: environmental degradation; the emergence of new residential clusters that are not in accordance with spatial planning directions; illegal logging; forest fires; garbage collection.

\section{REFERENCES}

[1] B. Galleli, N. E. B. Teles, J. A. R. dos Santos, M. S. Freitas-Martins, and F. Hourneaux Junior, "Sustainability university rankings: a comparative analysis of UI green metric and the times higher education world university rankings," Int. J. Sustain. High. Educ., vol. ahead-of-p, no. ahead-of-print, Jan. 2021, doi: 10.1108/IJSHE-12-2020-0475.

[2] H. M. Alshuwaikhat and I. Abubakar, "An integrated approach to achieving campus sustainability: assessment of the current campus environmental management practices," J. Clean. Prod., vol. 16, no. 16, pp. 1777-1785, 2008, doi: https://doi.org/10.1016/j.jclepro.2007.12.002.

[3] E. Rall, R. Hansen, and S. Pauleit, "The added value of public participation GIS (PPGIS) for urban green infrastructure planning," Urban For. Urban Green., vol. 40, pp. 264-274, 2019, doi: https://doi.org/10.1016/j.ufug.2018.06.016.

[4] D. Dizdaroglu, "The Role of Indicator-Based Sustainability Assessment in Policy and the DecisionMaking Process: A Review and Outlook," Sustainability, vol. 9, no. 6. 2017, doi: 10.3390/su9061018. [5] A. Disterheft, S. Caeiro, U. M. Azeiteiro, and W. Leal Filho, "Sustainability Science and Education for Sustainable Development in Universities: A Way for Transition BT - Sustainability Assessment Tools in Higher Education Institutions: Mapping Trends and Good Practices Around the World," S. Caeiro, W. L. Filho, C. Jabbour, and U. M. Azeiteiro, Eds. Cham: Springer International Publishing, 2013, pp. 3-27.

[6] D. Vine, L. Buys, and R. Aird, "The use of amenities in high density neighbourhoods by older urban Australian residents," Landsc. Urban Plan., vol. 107, no. 2, pp. 159-171, 2012, doi: https://doi.org/10.1016/j.landurbplan.2012.05.013.

[7] R. J. Koester, J. Eflin, and J. Vann, "Greening of the campus: a whole-systems approach," J. Clean. Prod., vol. 14, no. 9, pp. 769-779, 2006, doi: https://doi.org/10.1016/j.jclepro.2005.11.055. 
Vol. 4, Issue.6, Nov-Dec 2021, p no. 40-62

[8] K. Manninen, S. Koskela, R. Antikainen, N. Bocken, H. Dahlbo, and A. Aminoff, "Do circular economy business models capture intended environmental value propositions?” J. Clean. Prod., vol. 171, pp. 413-422, 2018, doi: https://doi.org/10.1016/j.jclepro.2017.10.003.

[9] K. B. Atici, G. Yasayacak, Y. Yildiz, and A. Ulucan, "Green University and academic performance: An empirical study on UI GreenMetric and World University Rankings," J. Clean. Prod., vol. 291, p. 125289, 2021, doi: https://doi.org/10.1016/j.jclepro.2020.125289.

[10] X. Yuan, J. Zuo, and D. Huisingh, “Green Universities in China - what matters?” J. Clean. Prod., vol. 61, pp. 36-45, 2013, doi: https://doi.org/10.1016/j.jclepro.2012.12.030.

[11] A. D. Guerry et al., "Modeling benefits from nature: using ecosystem services to inform coastal and marine spatial planning," Int. J. Biodivers. Sci. Ecosyst. Serv. Manag., vol. 8, no. 1-2, pp. 107121, Jun. 2012, doi: 10.1080/21513732.2011.647835.

[12] L. Ramakreshnan, C. S. Fong, N. M. Sulaiman, and N. Aghamohammadi, "Motivations and built environment factors associated with campus walkability in the tropical settings," Sci. Total Environ., vol. 749, p. 141457, 2020, doi: https://doi.org/10.1016/j.scitotenv.2020.141457.

[13] J. Dlouhá, P. Glavič, and A. Barton, "Higher education in Central European countries - Critical factors for sustainability transition," J. Clean. Prod., vol. 151, pp. 670-684, 2017, doi: https://doi.org/10.1016/j.jclepro.2016.08.022.

[14] H. Snyder, "Literature review as a research methodology: An overview and guidelines," J. Bus. Res., vol. 104, pp. 333-339, 2019, doi: https://doi.org/10.1016/j.jbusres.2019.07.039.

[15] L. F. Cabeza, L. Rincón, V. Vilariño, G. Pérez, and A. Castell, "Life cycle assessment (LCA) and life cycle energy analysis (LCEA) of buildings and the building sector: A review," Renew. Sustain. Energy Rev., vol. 29, pp. 394-416, 2014, doi: https://doi.org/10.1016/j.rser.2013.08.037.

[16] H. M. Alshuwaikhat, Y. A. Adenle, and B. Saghir, "Sustainability Assessment of Higher Education Institutions in Saudi Arabia," Sustainability, vol. 8, no. 8. 2016, doi: 10.3390/su8080750.

[17] N. Suwartha and R. F. Sari, "Evaluating UI GreenMetric as a tool to support green universities development: assessment of the year 2011 ranking," J. Clean. Prod., vol. 61, pp. 46-53, 2013, doi: https://doi.org/10.1016/j.jclepro.2013.02.034.

[18] E. Setyowati, A. R. Harani, and Y. N. Falah, "Green Building Design Concepts of Healthcare Facilities on the Orthopedic Hospital in the Tropics," Procedia - Soc. Behav. Sci., vol. 101, pp. 189199, 2013, doi: https://doi.org/10.1016/j.sbspro.2013.07.192. 
Vol. 4, Issue.6, Nov-Dec 2021, p no. 40-62

[19] J. Pelcher, B. P. McCullough, and S. Trendafilova, "Collegiate athletics environmental sustainability efforts within STARS reporting," Int. J. Sustain. High. Educ., vol. 22, no. 2, pp. 328 343, Jan. 2021, doi: 10.1108/IJSHE-07-2020-0246.

[20] F. Steiner, "Frontiers in urban ecological design and planning research," Landsc. Urban Plan., vol. 125, pp. 304-311, 2014, doi: https://doi.org/10.1016/j.landurbplan.2014.01.023.

[21] G. Brown and M. Kyttä, "Key issues and research priorities for public participation GIS (PPGIS): A synthesis based on empirical research,” Appl. Geogr., vol. 46, pp. 122-136, 2014, doi: https://doi.org/10.1016/j.apgeog.2013.11.004.

[22] M. Wimala, E. Akmalah, I. Irawati, and M. Sururi, "Overcoming the Obstacles to Green Campus Implementation in Indonesia," J Civil, Environ. Struct. Constr. Archit. Eng., vol. 10, no. December, pp. 1352-1357, 2016.

[23] A. Martos, R. Pacheco-Torres, J. Ordóñez, and E. Jadraque-Gago, "Towards successful environmental performance of sustainable cities: Intervening sectors. A review," Renew. Sustain. Energy Rev., vol. 57, pp. 479-495, 2016, doi: https://doi.org/10.1016/j.rser.2015.12.095.

[24] C. S. Lai et al., "A Review of Technical Standards for Smart Cities," Clean Technologies, vol. 2, no. 3. 2020, doi: 10.3390/cleantechnol2030019.

[25] G. Brown, "PPGIS for regional and env...," J. Urban Reg. Inf. Syst. Assoc., vol. 25, no. 2, pp. $7-18,2012$.

[26] B. A. Norton, A. M. Coutts, S. J. Livesley, R. J. Harris, A. M. Hunter, and N. S. G. Williams, "Planning for cooler cities: A framework to prioritise green infrastructure to mitigate high temperatures in urban landscapes," Landsc. Urban Plan., vol. 134, pp. 127-138, 2015, doi: https://doi.org/10.1016/j.landurbplan.2014.10.018.

[27] T. A. Scandura and E. A. Williams, "Research Methodology In Management: Current Practices, Trends, And Implications For Future Research,” Acad. Manag. J., vol. 43, no. 6, pp. 12481264, Dec. 2000, doi: 10.5465/1556348.

[28] J. C. Radcliffe, "Chapter 1 - History of Water Sensitive Urban Design/Low Impact Development Adoption in Australia and Internationally," A. K. Sharma, T. Gardner, and D. B. T.-A. to W. S. U. D. Begbie, Eds. Woodhead Publishing, 2019, pp. 1-24.

[29] B. Zhu, C. Zhu, and B. Dewancker, "A study of development mode in green campus to realize the sustainable development goals,” Int. J. Sustain. High. Educ., vol. 21, no. 4, pp. 799-818, Jan. 2020, doi: 10.1108/IJSHE-01-2020-0021. 